\title{
Hubungan Antara Perilaku Dengan Penggunaan Alat Pelindung Diri Pada Petani Pengguna Pestisida Di Desa Tonrong Rijang Kecamatan Baranti Kabupaten Sidenreng Rappang
}

\author{
Ashari Rasjid, Zaenab, Nurmin \\ Politeknik Kesehatan Kemenkes Makassar \\ asharirasjid63@gmail.com
}

\begin{abstract}
Agriculture is one of the most important areas in meeting the needs of the community, where agricultural life is closely related to the use of pesticides that can cause health problems. To minimize health problems is one effort that can be done with the use of a complete APD. The type of research used is an analytical survey with Cross Sectional approach with the population of rice farmers in Tonrong Rijang Village Baranti Subdistrict Sidenreng Rappang Regency as many as $334 \mathrm{HH}$ with sample $67 \mathrm{HH}$. Determination of the number of samples in this study was determined by using Cluster method and data retrieval was done using Random Sampling Method. Data processing is done by using Chi Square test with SPSS 25, Microsoft excel, and Microsoft word. The results of this study explain that farmers with high knowledge level of 44 people (66\%), who have high APD usage as many as 21 people (31\%) and who have the use of PPE while as many as 23 people (34\%). Farmers with a moderate level of knowledge of 23 people (34\%), who had high APD usage of 7 people (11\%) and those with PPE were $16(24 \%)$. Farmers who have a high attitude (good) as many as 55 people (82\%) who use high APD as many as 21 people (31\%), while those using PPE were as many as 34 people (51\%). Farmers who have moderate attitude (less good) as many as 12 people (18\%) who use high APD as many as 7 people (10\%) and who use PPE while as many as 5 people (8\%). Based on result of chi square test that obtained is $p$ value 0,173 ( $p$ value> $0,05)$ on knowledge and $p$ value $0,2(p$ value $>0,05)$ at attitude. So it can be concluded that there is no relationship between behavior with the use of personal protective equipment on pesticide user farmers in Tonrong Rijang Village Baranti SubDistrict Sidenreng Rappang.
\end{abstract}

Keywords: Farmer, Personal Protective Equipment, Knowledge, Attitude

\section{ABSTRAK}

Pertanian merupakan salah satu bidang terpenting dalam pemenuhan kebutuhan masyarakat, dimana kehidupan pertanian sangat erat kaitannya dengan penggunaan pestisida yang dapat menimbulkan gangguan kesehatan. Untuk meminimalisir gangguan kesehatan tersebut salah satu upaya yang dapat dilakukan dengan penggunaan APD yang lengkap. Jenis penelitian yang digunakan adalah survei analitik dengan pendekatan Cross Sectional dengan populasi yaitu petani padi yang ada di Desa Tonrong Rijang Kecamatan Baranti Kabupaten Sidenreng Rappang sebanyak 334 KK dengan sampel $67 \mathrm{KK}$. Penentuan jumlah sampel dalam penelitian ini ditentukan dengan menggunakan metode Cluster dan pengambilan data dilakukan menggunakan Metode Random Sampling. Pengolahan data dilakukan dengan menggunakan uji Chi Square dengan SPSS 25, Microsoft excel, dan Microsoft word. Hasil dari penelitian ini menjelaskan bahwa petani yang memiliki tingkat pengetahuan tinggi sebanyak 44 orang $(66 \%)$, yang memiliki penggunaan APD tinggi sebanyak 21 orang(31\%) dan yang memiliki penggunaan APD sedang sebanyak 23 orang(34\%). Petani yang memiliki tingkat pengetahuan sedang sebanyak 23 orang(34\%), yang memiliki penggunaan APD tinggi sebanyak 7 orang(11\%) dan yang memiliki penggunaan APD sedang sebanyak 16 orang(24\%). Petani yang memiliki sikap tinggi(baik) sebanyak 55 orang(82\%) yang menggunakan APD tinggi sebanyak 21 orang(31\%), sedangkan yang menggunakan APD sedang sebanyak 34 orang(51\%). Petani yang memilki sikap sedang(kurang baik) sebanyak 12 orang(18\%) yang menggunakan APD tinggi sebanyak 7 orang(10\%) dan yang menggunakan APD sedang sebanyak 5 orang( $8 \%$ ). Berdasarkan hasil uji chi square yang diperoleh adalah $p$ value 0,173 ( $p$ value $>0,05$ ) pada pengetahuan dan $p$ value 0,2 ( $p$ value $>0,05$ ) pada sikap. Sehingga dapat disimpulkan bahwa tidak ada hubungan antara perilaku dengan penggunaan alat pelindung diri pada petani pengguna pestisida di Desa Tonrong Rijang Kecamatan Baranti Kabupaten Sidenreng Rappang.

Kata kunci: Petani,Alat Pelindung Diri, Pengetahuan, Sikap

\section{PENDAHULUAN}

Pertanian merupakan salah satu bidang terpenting dalam pemenuhan kebutuhan untuk masyarakat dimana Negara Indonesia adalah Negara agraris yang sebagian besar penduduknya bermata pencaharian di bidang pertanian. Jumlah petani mencapai $40 \%$ dari jumlah total tenaga kerja di Indonesia atau sekitar 46,7 juta jiwa. Sebagai Negara agraris, mayoritas penduduk Indonesia telah memanfaatkan sumber daya alam untuk menunjang kebutuhan hidupnya dan salah satunya ialah menggantungkan hidup pada sektor pertanian. Dalam hal tersebut sektor pertanian memiliki peran yang sangat penting karena sebagai penghasil pangan yang cukup besar bagi penduduk yang jumlahnya terus meningkat setiap tahun. Dengan meningkatnya jumlah penduduk setiap tahunnya, masyarakat mulai berpikir untuk meningkatkan hasil produksinya dalam sektor pertanian, salah satu cara mereka adalah menggunakan pestisida untuk menurunkan

Vol. XIV No. 1, Juni 2019

DOI: https://doi.org/10.32382/medkes.v14i1.790 
faktor-faktor pengganggu produksi mereka seperti hama. (Usman Rifai. 2017).

Penggunaan pestisida secara besarbesaran dapat menimbulkan gangguan kesehatan terutama pada petani penyemprot. Salah satu dampak yang ditimbulkan akibat penggunaan pestisida adalah keracunan pada petani padi. Hal tersebut perlu menjadi perhatian bidang kesehatan masyarakat terutama masyarakat di Negara berkembang. Salah satu upaya untuk mencegah keracunan pestisida pada petani adalah dengan penggunaan Alat Pelindung Diri (APD) lengkap, seperti masker, pakaian kerja, sepatu boot, dan sarung tangan. (Endah Retnani Wismaningsih, 2015)

World Health Organization (WHO) dampak negatif yang di timbulkan pestisida bagi kesehatan masyarakat sangat beracun dan berbahaya. Kontak langsung dengan pestisida ini berisiko keracunan akut maupun kronis. Sakit kepala, mual, muntah dan sebagainya bahkan iritasi pada kulit dan kebutaan merupakan gejala keracunan akut dari pestisida. Data dari Organisasi Kesehatan Dunia (WHO), 1-5 juta kasus keracunan pestisida terjadi pada pekerja di sektor pertanian dimana sebagian besar kasus tersebut terjadi di Negara berkembang yang 20.000 jiwa diantaranya berakibat fatal akibat penggunaan pestisida. (Frity,2017).

Berdasarkan gambaran permasalahan di atas, peneliti tertarik untuk meneliti lebih lanjut apakah ada hubungan antara perilaku dengan penggunaan alat pelindung diri pada petani pengguna pestisida di Desa Tonrong Rijang Kecamatan Baranti Kabupaten Sidenreng Rappang

\section{BAHAN DAN METODE}

\section{Lokasi Penelitian:}

Lokasi penelitian dilakukan di Desa Tonrong Rijang Kecamatan Baranti Kabupaten Sidenreng Rappang. Desa Tonrong Rijang merupakan wilayah datar $100 \%$. Sebagian besar wilayahnya berupa lahan pertanian, peternakan, dan perkebunan dengan tingkat kesuburan tanah rata-rata sedang. Luas wilayah Desa Tonrong Rijang sekitar $340 \mathrm{ha} / \mathrm{m}^{2}$ dengan 1.318 jiwa dengan 338 kepala keluarga.

\section{Desain dan Variabel Penelitian}

Petani merupakan mata pencaharian utama masyarakat di Desa Tonrong Rijang Kecamatan Baranti Kabupaten Sidenreng Rappang. Aktivitas Petani padi sangat dekat dengan penggunaan pestisida yang berpotensi menyebabkan dampak negatif pada petani tersebut, seperti keracunan dan akumulasi pestisida dalam darah petani . Maka dari itu dibutuhkan Alat pelindung diri (APD) sebagai upaya untuk mengurangi dampak negatif penggunaan pestisida. Hal tersebut tentunya sangat dipengaruhi oleh faktor perilaku diantaranya pengetahuan dan sikap Petani dalam penggunaan alat pelindung diri (APD) pada saat menggunakan pestisida.

Adapun variabel penelitian pada penelitian ini terdiri dari 3 variabel. Yaitu variabel bebas yang terdiri dari pengetahuan dan sikap, variabel terikat yaitu penggunaan alat pelindung diri pada petani, serta variabel pengganggu yang terdiri dari tingkat penghasilan dan umur.

\section{Populasi dan Sampel}

Populasi dalam penelitian ini adalah seluruh petani padi di desa Tonrong Rijang Kecamatan Baranti Kabupaten Sidenreng Rappang yaitu $334 \mathrm{KK}$.

Sampel dalam penelitian ini adalah masyarakat desa Tonrong Rijang Kecamatan Baranti Kabupaten Sidenreng Rappang yang bekerja sebagai petani padi, yaitu $67 \mathrm{KK}$, penentuan jumlah sampel dalam penelitian ini ditentukan dengan menggunakan metode Cluster dan Pengambilan Data dilakukan menggunakan Metode Random Sampling berdasarkan buku Muri yusuf 2017 dan Buku Suharsimi Arikunto, 1996.

Untuk menentukan besarnya sampel yang akan diambil dijelaskan oleh Suharsimi Arikunto, yaitu apabila subyeknya kurang dari 100 , lebih baik semua populasi diambil, selanjutnya apabila subyeknya besar atau lebih dari 100, maka dapat diambil antara 10$15 \%$ atau $20-25 \%$.

Berdasarkan pendapat diatas, maka peneliti akan mengambil sampel sebesar $20 \%$ dari jumlah populasi. Karena jumlah populasi adalah lebih dari 100 orang di Desa Tonrong Rijang dengan perhitungan sebagai berikut :

$$
\begin{array}{ll}
\text { Dusun Mattonrong Salo : } 191 \mathrm{KK} \\
\text { Dusun Tonrong Rijang } & : 143 \mathrm{KK} \\
191 \mathrm{KK} \times 20 \% & : 38 \mathrm{KK} \\
143 \mathrm{KK} \times 20 \% & : 29 \mathrm{KK}+ \\
\hline & 64 \mathrm{KK}
\end{array}
$$

\section{Pengumpulan data}

Sumber data terdiri dari 2 yaitu data primer yang diambil secara langsung oleh peneliti dan data sekunder yang diperoleh dari sumber lain seperti, profil desa, buku, jurnal, dan karya tulis ilmiah. Pengumpulan data 
dilakukan dengan menggunakan metode observasi dan wawancara dengan menggunakan lembar observasi atau kuesioner.

\section{Analisa Data (Jika memakai program} statistic, tuliskan uji utama apa yang digunakan)

Analisa data dilakukan dengan menggunakan tabel beserta pembahasannya dan disimpulkan dengan menggunakan menggunakan uji Chi Square dengan SPSS 25, Microsoft excel, dan Microsoft word.

\section{HASIL}

1. Hubungan antara pengetahuan Petani dengan penggunaan alat pelindung diri

Tabel 4.1

Distribusi Responden berdasarkan Pengetahuan tentang APD

\begin{tabular}{ccc}
\hline $\begin{array}{c}\text { Pengetahua } \\
\mathbf{n}\end{array}$ & Jumlah & $\begin{array}{c}\text { Persentase( } \\
\%)\end{array}$ \\
\hline Tinggi & 44 & 66 \\
Sedang & 23 & 34 \\
Rendah & 0 & 0 \\
Total & 67 & 100 \\
\hline
\end{tabular}

Sumber: Data Primer 2018

Adapun hasil pengujian hubungan antara pengetahuan dengan penggunaan alat pelindung diri pada petani, sebagai berikut:

Tabel 4.2

Hubungan antara pengetahuan petani dengan penggunaan APD

\begin{tabular}{|c|c|c|c|c|c|c|}
\hline & & \multicolumn{3}{|c|}{ Penggunaan APD } & \multirow{2}{*}{$\begin{array}{l}\text { Jum } \\
\text { lah }\end{array}$} & \multirow{2}{*}{$\begin{array}{l}\text { P } \\
\text { Val } \\
\text { ue }\end{array}$} \\
\hline & & $\begin{array}{l}\text { Ren } \\
\text { dah }\end{array}$ & $\begin{array}{l}\text { Sed } \\
\text { ang }\end{array}$ & $\begin{array}{l}\text { Tin } \\
\text { ggi }\end{array}$ & & \\
\hline \multirow{3}{*}{$\begin{array}{c}\text { Penge } \\
\text { tahua } \\
\text { n }\end{array}$} & Tinggi & 0 & 23 & 21 & 44 & \multirow{4}{*}{$\begin{array}{l}0.1 \\
73\end{array}$} \\
\hline & $\begin{array}{c}\text { Seda } \\
\text { ng }\end{array}$ & 0 & 16 & 7 & 23 & \\
\hline & $\begin{array}{l}\text { Rend } \\
\text { ah }\end{array}$ & 0 & 0 & 0 & 0 & \\
\hline \multicolumn{2}{|c|}{ Jumlah } & 0 & 39 & 28 & 67 & \\
\hline
\end{tabular}

Vol. XIV No. 1, Juni 2019

DOI: https://doi.org/10.32382/medkes.v14i1.790
2. Hubungan antara sikap Petani dengan penggunaan alat pelindung diri

Tabel 4.3

Distribusi Responden berdasarkan Sikap terhadap APD

\begin{tabular}{ccc}
\hline Sikap & Jumlah & Persentase(\%) \\
\hline Tinggi & 55 & 82 \\
Sedang & 12 & 18 \\
Rendah & 0 & 0 \\
Total & $\mathbf{6 7}$ & $\mathbf{1 0 0}$ \\
\hline
\end{tabular}

Sumber: Data Primer 2018

Adapun hasil pengujian hubungan antara sikap dengan penggunaan alat pelindung diri pada petani, sebagai berikut:

Tabel 4.4

Hubungan antara sikap petani dengan penggunaan APD

\begin{tabular}{|c|c|c|c|c|c|c|}
\hline & & \multicolumn{3}{|c|}{ Penggunaan APD } & \multirow{2}{*}{$\begin{array}{c}\text { Juml } \\
\text { ah }\end{array}$} & \multirow{2}{*}{$\begin{array}{c}\mathbf{P} \\
\text { Valu } \\
\mathbf{e}\end{array}$} \\
\hline & & $\begin{array}{l}\text { Ren } \\
\text { dah }\end{array}$ & $\begin{array}{c}\text { Sedan } \\
\mathrm{g}\end{array}$ & $\begin{array}{c}\text { Ting } \\
\text { gi }\end{array}$ & & \\
\hline \multirow{3}{*}{$\begin{array}{c}\text { Sika } \\
\mathbf{p}\end{array}$} & Tinggi & 0 & 34 & 21 & 55 & 0.2 \\
\hline & Sedang & 0 & 5 & 7 & 12 & \\
\hline & Rendah & 0 & 0 & 0 & 0 & \\
\hline \multicolumn{2}{|c|}{ Jumlah } & 0 & 39 & 28 & 67 & \\
\hline
\end{tabular}

Sumber: Data Primer 2018

Adapun hasil observasi dan wawancara tentang penggunaan alat pelindung diri pada petani pada saat mengaplikasikan pestisida, sebagai berikut:

Tabel 4.5

Distribusi Responden berdasarkan Penggunaan APD

\begin{tabular}{ccc}
\hline $\begin{array}{c}\text { Penggunaan } \\
\text { APD }\end{array}$ & Jumlah & Persentase(\%) \\
\hline Tinggi & 28 & 42 \\
Sedang & 39 & 58 \\
Rendah & 0 & 0 \\
Total & $\mathbf{6 7}$ & $\mathbf{1 0 0}$ \\
\hline Sumber: Data Primer 2018
\end{tabular}

Sumber: Data Primer 2018

\section{PEMBAHASAN}

1. Hubungan antara pengetahuan Petani dengan penggunaan alat pelindung diri Berdasarkan hasil penelitian menunjukkan bahwa tidak ada hubungan yang signifikan antara pengetahuan dengan penggunaan alat pelindung diri 
(APD) pada petani pengguna pestisida di Desa Tonrong Rijang Kecamatan Baranti Kabupaten Sidenreng Rappang. Hal ini didasarkan pada hasil uji chi square yang diperoleh adalah $p$ value 0,173 ( $p$ value $>0,05$ ). Hasil penelitian ini mejelaskan bahwa sebagian petani mempunyai tingkat pengetahuan tinggi yaitu sebanyak 44 orang $(66 \%)$ dan tingkat pengetahuan sedang 23 orang(34\%). Dimana Petani yang memiliki tingkat pengetahuan tinggi sebanyak 44 orang(66\%), yang memiliki penggunaan APD tinggi sebanyak 21 orang(31\%) dan yang memiliki penggunaan APD sedang sebanyak 23 orang(34\%). Petani yang memiliki tingkat pengetahuan sedang sebanyak 23 orang(34\%), yang memiliki penggunaan APD tinggi sebanyak 7 orang(11\%) dan yang memiliki penggunaan APD sedang sebanyak 16 orang( $24 \%)$.

Hasil penelitian ini menjelaskan bahwa sebagian besar petani yang memiliki pengetahuan tinggi tentang penggunaan alat pelindung diri(APD) tidak menggunakan alat pelindung diri(APD) secara lengkap, dimana sebagian besar petani tidak menggunakan masker, tidak menggunakan sarung tangan, dan tidak menggunakan sepatu boot. Dalam hal ini tindakan untuk menggunakan alat pelindung diri masih kurang.

Hasil penelitian ini tidak sejalan dengan penelitian Faris Khamdani (2009). Hasil penelitian Faris Khamdani (2009) tentang Hubungan antara Pengetahuan dan Sikap dengan Pemakaian Alat pelindung Diri Pestisida Semprot pada Petani di Desa Angk atan Kidul Pati Tahun 2009 didapatkan hasil bahwa responden yang mempunyai pengetahuan kurang dan tidak memakai APD lengkap sebanyak 32 orang atau $94,1 \%$, sedangkan responden yang memiliki pengetahuan baik dan cukup yang tidak memakai APD lengkap sejumlah 13 orang atau $28,3 \%$. Responden dengan pengetahuan yang kurang dan memakai APD lengkap sejumlah 2 orang atau 5,9\% sedangkan responden yang mempunyai pengetahuan baik dan cukup yang memakai APD lengkap 33 orang atau $71,7 \%$.

Hasil penelitian ini juga tidak sejalan dengan penelitian Wismaningsih 2015 tentang faktor yang berhubungan dengan penggunaan alat pelindung diri(APD) pada petani penyemprot di Kecamatan Ngantru Kabupaten
Tulungagung dari hasil analisis Fisher's Exact Test menunjukkan bahwa pengetahuan mempunyai hubungan yang signifikan terhadap penggunaan APD dengan nilai $p 0,001 \quad(p<0,05)$. Semakin tinggi pengetahuan petani terhadap pentingnya penggunaan APD maka semakin baik perilaku petani dalam penggunaan APD.

Akan tetapi, hasil penelitian ini sejalan dengan penelitian Shobib 2013 tentang hubungan antara pengetahuan dan sikap dengan praktik pemakaian (APD) alat pelindung diri pada petani pengguna pestisida di Desa Curut Kec Penawangan Kab Grobogan tahun 2013 dari hasil uji statistik pengetahuan dengan praktik didapatkan $p$ value $0,658(p>0,05)$ menunjukkan tidak ada hubungan yang bermakna antara pengetahuan dengan praktik pemakaian APD pada petani pengguna pestisida. Perilaku atau praktik petani dalam penggunaan APD dipengaruhi banyak faktor, walaupun pengetahuan petani baik terhadap penggunaan APD saat berinteraksi dengan pestisida, akan tetapi dalam praktiknya bisa saja tidak sesuai, bisa dari ketersediaan APD, kenyamanan, musim dan cuaca yang tidak memungkinkan bahkan karena mengikuti perilaku dari orang-orang atau sesama petani, sehingga pengetahuan belum tentu berpengaruh atau berhubungan dengan praktik atau perilaku seseorang.

Dalam penelitian ini sebagian besar petani berumur $>50$ tahun dengan masa kerja $>10$ tahun dan sebagian besar petani tidak tamat Sekolah Dasar(SD) dan beberapa diantaranya memiliki pendidikan sampai jenjang Sekolah Menengah Atas(SMA). Petani yang tidak tamat Sekolah Dasar(SD) sebagian besar memiliki tingkat pengetahuan sedang, sedangkan petani yang memilki pendidikan sampai dengan Sekolah Menengah Atas(SMA) memiliki pengetahuan tinggi. Petani yang memiliki pengetahuan sedang( Petani yang tidak tamat Sekolah Dasar) sebagian besar tidak menggunakan alat pelindung diri yang lengkap, sedangkan petani yang memiliki pengetahuan tinggi( Petani yang memiliki pendidikan sampai jenjang Sekolah Menengah Atas) sebagian besar menggunakan alat pelindung diri yang lengkap. Hal ini menunjukkan bahwa pendidikan formal memberikan pengaruh besar dalam membuka wawasan dan 
pemahaman terhadap nilai baru yang ada di lingkungannya.

Seseorang dengan tingkat pendidikan tinggi akan lebih mudah untuk memahami perubahan yang terjadi di lingkungannya dan orang tersebut akan menyerap perubahan tersebut apabila merasa bermanfaat bagi dirinya. Seseorang yang pernah mengenyam pendidikan formal diperkirakan akan lebih mudah menerima dan mengerti tentang pesan-pesan kesehatan melalui penyuluhan maupun media massa. ( Soemirat Slamet, 2003 dalam Faris Khamdani)

$\begin{array}{rcr} & \text { Merujuk pada teori Lawrence } \\ \text { Green } 1980 & \text { dalam penelitian }\end{array}$
Wismaningsih bahwa pengetahuan termasuk dalam salah satu faktor perubah perilaku yaitu faktor predisposeing. Pengetahuan merupakan hasil dari tahu setelah seseorang melakukan penginderaan pada suatu objek tertentu. Akan tetapi, dari hasil penelitian ini meskipun responden memiliki tingkat pengetahuan yang baik tetapi masih banyak responden yang tidak menggunakan alat pelindung diri yang lengkap, terutama penggunaan sarung tangan, masker dan sepatu boot. Alasan responden tidak menggunakan alat pelindung diri yang lengkap karena masih kurangnya pemahaman responden tentang syarat-syarat alat pelindung diri dan manfaat alat pelindung diri. Sebagian besar petani tidak menggunakan alat pelindung diri karena merasa terganggu atau tidak nyaman terutama penggunaan sarung tangan, masker, dan sepatu boot. Beberapa responden beranggapan bahwa mereka tidak merasakan dampak yang ditimbulkan dari tidak menggunakan alat pelindung diri dan beberapa responden juga beranggapan bahwa meskipun mereka menggunakan alat pelindung diri yang lengkap pada saat penyemprotan mereka tetap merasakan dampak yang ditimbulkan dari kegiatan penyemprotan seperti merasa pusing. Dampak tersebut timbul ketika petani menyemprot dengan cara yang salah pada saat penyemprotan pestisida, seperti petani yang menyemprot berlawanan arah dengan arah angin dan melakukan penyemprotan pada siang hari.

Dari permasalahan tersebut, maka perlu diupayakan untuk meningkatkan pengetahuan dan pemahaman petani agar lebih memperhatikan penggunaan alat pelindung diri (APD), khususnya tentang dampak negatif atau bahaya yang dapat ditimbulkan dari pestisida apabila tidak menggunakan alat pelindung diri,memberikan penyuluhan dan simulasi tentang tata cara penggunaan alat pelindung diri yang lengkap dengan baik dan benar, seperti topi, masker, sarung tangan, baju lengan panjang, celana panjang dan sepatu boot dan bahaya dari tidak menggunakan APD serta perlu adanya pemasangan poster tentang alat pelindung diri pada petani yang wajib digunakan guna mengingatkan petani serta menumbuhkan kesadaran petani akan pentingnya keselamatan dan kesehatan dalam bekerja.

\section{Hubungan Sikap dengan Penggunaan Alat Pelindung Diri pada Petani Pengguna Pestisida di Desa Tonrong Rijang}

Berdasarkan hasil penelitian menunjukkan bahwa tidak ada hubungan yang signifikan antara sikap dengan penggunaan alat pelindung diri (APD) pada petani pengguna pestisida di Desa Tonrong Rijang Kecamatan Baranti Kabupaten Sidenreng Rappang. Hal ini didasarkan pada hasil uji chi square yang diperoleh adalah $p$ value 0,2 ( $p$ value $>0,05$ ). Hasil penelitian ini mejelaskan bahwa sebagian besar petani mempunyai sikap tinggi yaitu sebanyak 55 orang (82\%) dan sikap sedang 12 orang(18\%). Dimana Petani yang memiliki sikap tinggi(baik) terhadap penggunaan APD yang menggunakan APD tinggi sebanyak 21 orang(31\%), sedangkan yang menggunakan APD sedang sebanyak 34 orang(51\%). Petani yang memilki sikap sedang(kurang baik) yang menggunakan APD tinggi sebanyak 7 orang $(10 \%)$ dan yang menggunakan APD sedang sebanyak 5 orang $(8 \%)$.

Hasil penelitian ini menjelaskan bahwa meskipun sebagian besar petani memiliki sikap tinggi(baik) terhadap penggunaan alat pelindung diri(APD), mereka tetap tidak menggunakan alat pelindung diri(APD) secara lengkap dalam artian tindakan untuk menggunakan alat pelindung diri masih kurang. Sehingga dapat dilihat bahwa sikap tidak selalu mencerminkan tindakan seseorang atau tindakan seseorang seringkali bertentangan dengan sikapnya.

Hasil penelitian ini tidak sejalan dengan penelitian Wismaningsih 2015 
tentang faktor yang berhubungan dengan penggunaan alat pelindung diri (APD) pada petani penyemprot di Kecamatan Ngantru Kabupaten Tulungagung dari hasil analisis Fisher's Exact Test menunjukkan bahwa sikap mempunyai hubungan yang signifikan terhadap penggunaan APD dengan nilai $p$ 0,000. Sikap seseorang berkaitan dengan persepsi, kepribadian, dan motivasi yang timbul sebagai reaksi dari pengalaman atau pengetahuan yang dimilikinya. Pengetahuan tentang APD yang baik disertai dengan reaksi yang positif menimbulkan kesadaran dan motivasi dari petani untuk melindungi dirinya dari bahaya pestisida dengan cara menggunakan APD.

Hasil penelitian ini sejalan dengan penelitian Shobib 2013 tentang hubungan antara pengetahuan dan sikap dengan praktik pemakaian (APD) alat pelindung diri pada petani pengguna pestisida di Desa Curut Kec Penawangan Kab Grobogan tahun 2013 dari hasil uji statistik sikap dengan praktik didapatkan $p$ value 0,902 $(p>0,05)$ menunjukkan tidak ada hubungan yang bermakna antara sikap dengan praktik pemakaian APD pada petani pengguna pestisida.

Hasil penelitian ini juga sejalan dengan penelitian Usman Rifai tentang Faktor-Faktor Yang Berhubungan Dengan Kepatuhan Penggunaan Alat Pelindung Diri Pada Petani Padi Di Dukuh Sodong Kelurahan Purwosari Kecamatan Mijen Kota Semarangtahun 2017. Berdasarkan hasil analisis hubungan antaran sikap dengan kepatuhan penggunaan Alat Pelindung Diri didapatkan bahwa dari 35 petani yang memiliki sikap baik, terdapat 8 petani yang memiliki sikap yang mematuhi penggunaan APD pada saat melakukan aktivitas bertani. Akan tetapi, terdapat 3 petani yang mempunyai APD tapi tidak mematuhi penggunaan APD saat bertani. Sedangkan pada kategori sikap yang kurang baik terdapat 10 petani yang mematuhi penggunaan APD pada saat melakukan aktivitas bertani dan terdapat 14 petani yang kurang mematuhi penggunaan APD. Dari hasil statistik, tidak ada hubungan antara Sikap dengan kepatuhan penggunaan APD dikarenakan di Dukuh Sodong, masih terdapat beberapa petani yang belum mematuhi penggunaan APD. Mereka menganggap bahwa pemakaian APD bisa menganggu pekerjaan serta perasaan yang tidak nyaman saat menggunakan APD

Sikap merupakan suatu kecenderungan untuk mengadakan tindakan terhadap suatu objek, dengan suatu cara yang menyatakan adanya tanda-tanda untuk menyenangi atau tidak menyenangi objek tersebut. Sikap hanyalah sebagian dari perilaku manusia. Sikap adalah reaksi atau respon yang masih tertutup dari seseorang terhadap stimulus atau objek. Sikap secara nyata menunjukkan konotasi adanya kesesuaian reaksi terhadap stimulus tertentu yang dalam kehidupan sehari-hari merupakan reaksi yang bersifat emosional terhadap stimulus sosial. (Soekidjo Notoatmodjo, 2003 dalam Fharis Khamdani 2009)

Dalam penelitian ini menunjukkan bahwa sikap petani terhadap penggunaan APD baik, akan tetapi meskipun sikap petani sudah baik ada beberapa faktor yang mempengaruhi penggunaan APD, seperti kenyamanan dalam bekerja. Sebagian besar petani tidak menggunakan alat pelindung diri sarung tangan yaitu sebanyak 59 responden atau $88 \%$ karena petani merasa tidak nyaman saat bekerja (mencampur dan menyemprot) memakai sarung tangan. Tangan merupakan salah satu aspek penting yang harus dilindungi karena petani menggunakan tangan untuk mengambil, mencampur dan menyemprotkan pestisida, penggunaan sarung tangan juga dapat mengurangi resiko masuknya pestisida dari kulit, sebanyak 54 responden atau $81 \%$ tidak menggunakan sepatu boot dalam bekerja karena merasa tidak nyaman, selain itu faktor cuaca juga mempengaruhi saat musim hujan akan sangat sulit bekerja dengan memakai sepatu boot, dan sebanyak 51 responden atau $76 \%$ tidak memakai masker karena merasa pengap atau kesulitan bernapas saat melakukan penyemprotan pestisida serta tidak tersedianya masker yang harus digunakan.

Pada penelitian ini sebagian besar petani memiliki masa kerja $>10$ tahun dan beberapa petani memiliki masa kerja $\leq 10$ tahun. Petani dengan masa kerja $>10$ tahun memiliki sikap yang tinggi (baik) terhadap penggunaan alat pelindung diri begitu juga dengan petani yang memiliki masa kerja $\leq 10$ tahun juga memiliki sikap yang baik terhadap penggunaan alat pelindung diri. Akan tetapi, baik petani dengan masa kerja $>10$ tahun maupun 
petani dengan masa kerja $\leq 10$ tahun yang memiliki sikap tinggi(baik) terhadap penggunaan alat pelindung diri sebagian besar memiliki penggunaan alat pelindung diri yang sedang dalam artian tidak menggunakan alat pelindung diri yang lengkap. Hal ini menunjukkan bahwa walaupun petani yang memilki masa kerja yang lama sekalipun, yang memilki pengalaman dalam melakukan pekerjaannya belum mampu menerapkan penggunaan APD yang lengkap dalam melindungi dirinya ketika melakukan penyemprotan.

Makin lama tenaga kerja bekerja, makin banyak pengalaman yang dimiliki tenaga kerja yang bersangkutan. Sebaliknya makin singkat masa kerja, maka makin sedikit pengalaman yang diperoleh. Pengalaman bekerja banyak memberikan keahlian dan keterampilan kerja, sebaliknya terbatasnya pengalaman kerja mengakibatkan tingkat keahlian dan keterampilan yang dimiliki makin rendah. Pengalaman merupakan reaksi yang merangsang kegiatan-kegiatan para petani dalam lingkungannya yang bersifat menyenangkan dan memberikan sifat positif. ( Milton, 1961 dalam Sitty)

Kerja sama antara Pemerintah setempat, baik Dinas Pertanian, Dinas Kesehatan, sampai kepada Perangkat Desa sangat dibutuhkan untuk memberikan penyuluhan maupun pelatihan atau simulasi kepada petani mengenai pentingnya penggunaan alat pelindung diri yang lengkap pada saat pengaplikasian pestisida agar resiko keterpaparan pestisida dapat diminimalisir dan produktivitas petani dapat meningkat.

\section{PENUTUP}

\section{KESIMPULAN}

Berdasarkan hasil penelitian ini, dapat disimpulkan bahwa tidak ada hubungan antara perilaku dengan penggunaan alat pelindung diri pada petani padi di Desa Tonrong Rijang Kecamatan Baranti Kabupaten Sidenreng Rappang, dimana $p$ value $=0,173(\mathrm{p}$ value $>0,05)$ pada pengetahuan dan $p$ value $=0,2$ ( $p$ value $>0,05)$ pada sikap.

\section{SARAN}

a. Bagi Petani

Petani diharapkan lebih meningkatkan pemahaman dan kesadaran akan pentingnya penggunaan alat pelindung diri
(APD) secara lengkap pada waktu bekerja dengan pestisida, terutama penggunaan masker, sarung tangan, dan sepatu boot dengan mengikuti kegiatan-kegiatan penyuluhan maupun pelatihan untuk meningkatkan keselamatan dan kesehatan kerja petani. Selain itu, untuk meningkatkan kenyamanan petani dalam menggunakan alat pelindung diri dapat dilakukan dengan cara mengikuti simulasi tentang cara penggunaan alat pelindung diri yang baik dan benar, sehingga dengan adanya penggunaan APD yang baik dan benar dapat meningkatkan kenyaman petani dalam menggunakan APD pada saat melakukan penyemprotan.

\section{b. Bagi Mahasiswa}

Hasil penelitian ini dapat dikembangkan lagi dengan melaksanakan penelitian lebih la njut dengan rancangan penelitian yang berbeda untuk mengetahui kadar cholinesterase pada darah petani pengguna pestisida, mengetahui hubungan antara masa kerja, pendidikan dan umur petani terhadap penggunaan alat pelindung diri (APD).

\section{c. Bagi Pemerintah Setempat}

Pemerintah setempat diharapkan dapat meningkatkan program promosi Kesehatan dan Keselamatan Kerja dengan melakukan pembinaan bagi petani pengguna pestisida lewat kerjasama dengan Puskesmas setempat dan rutin melakukan koordinasi dengan petani melalui pertemuanpertemuan antar petani serta memberikan reward kepada petani dalam rangka membentuk sikap postif petani dalam penggunaan alat pelindung diri(APD). 


\section{DAFTAR PUSTAKA}

Al Maqassary, Ardi. 2014. Keracunan Pestisida. (online)www.e-jurnal.com, diakses pada 2 Mei 2018.

Anizar. 2009. Teknik Keselamatan dan Kesehatan Kerja di Industri. Yogyakarta: Graha IImu.

Arikunto, Suharsimi. 1996. Prosedur Penelitian Suatu Pendekatan Praktik. Jakarta: PT Rineka Cipta. (buku online)repository.usu.ac.id, diakses pada 3 Januari 2018.

Badan Penelitian dan Pengembangan Pertanian. Teknik Penyemprotan Pestisida. (online) hortikultura.litbang. pertanian.go.id, diakses pada 2 Mei 2018.

Djali.2000. Pengukuran dalam bidang pendidikan. Universitas Negeri Jakarta: Program Pascasarjana. (buku online)

https://books.google.co.id/books,

Diakses pada 20 Desember 2017.

Djojosumarto, Panut. 2000. Teknik Aplikasi Pestisida Pertanian. Yogyakarta: Kanisius.

Fauzan, Alimah. 2017. Perempuan Paling Rentan Terpapar Racun Pestisida. (online) https://infest.or.id > Berita , Catatan Pengetahuan, diakses pada 23 November 2017.

Frity. 2017. Faktor Risiko Keterpaparan Pestisida Pada Petani Tanaman Hortikultura Di Perkebunan Wawo Kota Tomohon 2017.(online) https://ejournalhealth.com/index.php/k esmas/article/view/41, diakses pada 23 November 2017.

Ismail, Miftahul Jannah. 2017. Perilaku Petani penyemprot Pestisidan terhadap penggunaan Alat Pelindung Diri di desa Mandatte Kecamatan Anggeraja Kabupaten Enrekang .Makassar: Program Diploma III Jurusan Kesehatan Lingkungan, Politeknik Kesehatan Makassar. (KTI tidak diterbitkan)
Khamdani, Faris. 2009. Hubungan Antara Pengetahuan Dan Sikap dengan Pemakaian Alat Pelindung Diri Pestisida Semprot Pada Petani Di Desa Angkatan Kidul Pati Tahun 2009.(online) lib.unnes.ac.id/123/1/ 6094.pdf, diakses pada 23 November 2017.

Menteri Tenaga Kerja Dan Transmigrasi Republik Indonesia. 2010. Peraturan Menteri Tenaga Kerja Dan Transmigrasi Republik Indonesia Nomor Per.08/Men/Vii/2010 Tentang Alat Pelindung Diri. (online) https://betterwork.org/in-labourguide, diakses pada 23 November 2017.

Notoatmodjo, Soekidjo. 2012. Metodologi Penelitian Kesehatan. Jakarta : Rineka Cipta.

Notoatmodjo, Soekidjo. 2014. IImu Perilaku Kesehatan. Jakarta : Rineka Cipta.

Novisan. 2002. Petunjuk Pemakaian Pestisida. Jakarta: Agro Media Pustaka.

Panurat,Sitty Muawiyah. 2014. Faktor-Faktor yang Mempengaruhi Minat Petani Berusaha Tani Padi di Desa Sendangan Kecamatan Kakas Kabupaten Minahasa. Manado: Fakultas Pertanian Universitas Sam Ratulangi.(Online)

https://ejournal.unsrat.ac.id, diakses pada 1 Mei 2018.

Profil Desa Tonrong Rijang Kecamatan Baranti Kabupaten Sidenreng Rappang Tahun 2017.

Rahmawati, Yeviana Dwi. 2014. Pengaruh Faktor Karakteristik Petani dan Metode Penyemprotan terhadap Kadar Kolinesterase. (online)journal. unair.ac.id, diakses pada 23 November 2017. 
Rifai, Usman. 2017. Faktor-Faktor Yang Berhubungan Dengan Kepatuhan Penggunaan Alat Pelindung Diri Pada Petani Padi Di Dukuh Sodong Kelurahan Purwosari Kecamatan Mijen Kota Semarang tahun 2017. (online) eprints.dinus.ac.id/22506, diakses pada 23 November 2017.

Sahani, Wahyuni, dkk. 2017. Pedoman Karya Tulis IImiah. Jurusan Kesehatan Lingkungan : Politeknik Kesehatan Makassar Jurusan Kesehatan Lingkungan.

Shobib, Muhammad Nur, dkk. 2013. Hubungan Antara Pengetahuan dan Sikap dengan Praktik Pemakaian (APD) Alat Pelindung diri Pada Petani Pengguna Pestisida di Desa Curut Kec Penawangan Kab Grobogan Tahun 2013. (online) Eprints.dinus. ac.id, diakses pada 23 November 2017.

Thyar. 2013. Skripsi Kesling. (online) thyar69.blogspot.com/2013/11, diakses pada 23 November 2017.
Tribowo, Cecep dan mitha Erlisya Pusphandani. 2013. Kesehatan Lingkungan dan K3.Yogyakarta: Nuha Medika.

Wardhani, Putri Wisnu. 2009. Hubungan Nilai Budaya Uncertainty Avoidance dengan Tingkah. (online)lib.ui.ac.id. diakses pada 3 Januari 2013.

Wismaningsih, Endah Retnani dan Dianti las Oktaviasari. 2015. Faktor yang Berhubungan dengan Penggunaan Alat Pelindung Diri (APD) pada Petani Penyemprot di Kecamatan Ngantru Kabupaten Tulungagung. (online) https://ojs.iik.ac.id, diakses pada 23 November 2017.

Yusuf Muri. 2017. Metode Penelitian, Jakarta : PT. Fajar Interpratama Mandiri.(buku online) https://books. google.co.id, diakses pada 3 Januari 2017. 